\title{
Design, synthesis, docking study and cytotoxic activity evaluation of some novel letrozole analogs
}

\author{
Mohsen Vosooghi ${ }^{1}$, Loghman Firoozpour ${ }^{2}$, Abolfazl Rodaki ${ }^{2}$, Mahboobeh Pordeli ${ }^{3}$, Maliheh Safavi ${ }^{4}$, \\ Sussan K Ardestani ${ }^{3}$, Armin Dadgar ${ }^{1}$, Ali Asadipour ${ }^{5}$, Mohammad Hassan Moshafi ${ }^{5}$ and Alireza Foroumadi ${ }^{5,6^{*}}$
}

Background: Breast cancer is the most common type of female cancer. One class of hormonal therapy for breast cancer drugs -non steroidal aromatase inhibitors- are triazole analogues. In this work, some derivatives of these drugs was designed and synthesized. All synthesized compounds were evaluated for their cytotoxic activities on breast cancer cell lines (MDA-MB-231, T47D and MCF-7).

Methods: Our synthetic route for designed compounds started from 4-bromotolunitrile which was reacted with 1H-1,2,4-triazole to afford 4-(4-cyanobenzyl)-1,2,4-triazole. The reaction of later compound with aromatic aldehydes led to formation of the designed compounds. Eleven novel derivatives 1a-k were tested for their cytotoxic activities on three human breast cancer cell lines.

Results: Among the synthesized compound, 4-[2-(3-chlorophenyl)-1-(1H-1,2,4-triazol-1-yl)ethenyl]benzonitrile (1c) showed the highest activity against MCF-7 and MDA-MB-231 cell lines and 4-[2-(4-methoxyphenyl)-1-(1H-1,2,4-triazol1-yl)ethenyl]benzonitrile (1 h) exhibited highest activity against T47D cell line. According to cytotoxic activities results, compound 4-[2-(4-dimethylamino)-1-(1H-1,2,4-triazol-1-yl)ethenyl]benzonitrile (1 k) showed comparative activity against T47D and MDA-MB-231 cell lines with compound $(1 \mathrm{~h})$ and our reference drug Etoposide.

Conclusion: In the process of anti-cancer drug discovery, to find new potential anti-breast cancer agents, we designed and synthesized a novel series of letrozole analogs. Cytotoxicity evaluation revealed that compounds (1c) and (1 k) were the most potent compounds with comparative activity with Etoposide. The results revealed that $\pi-\pi$ interactions are responsible for the enzyme inhibitions of compounds (1 c) and (1 k).

Keyword: Breast cancer, Non-steroidal aromatase inhibitor, Cytotoxic activity

\section{Background}

Breast cancer is the most common female cancer. According to the American cancer society's report about $12 \%$ of women in the U.S. will develop some invasive breast cancer during their lifetime. However breast cancer treatment has a complicated process and problems, chemotherapy resistance, surgery and available anti-tumor drugs side effects make it more difficult to gain the appropriate treatment regimen; consequently, there is great demand to introduce new active compounds with more anticancer activity and less unwanted reaction $[1,2]$.

\footnotetext{
* Correspondence: aforoumadi@yahoo.com

${ }^{5}$ Neuroscience Research Center, Institute of Neuropharmacology, Kerman

University of Medicinal Sciences, Kerman, Iran

${ }^{6}$ Pharmaceutical Sciences Research Center, Tehran University of Medical Sciences, Tehran, Iran

Full list of author information is available at the end of the article
}

There is some different type of systemic therapy for breast cancer, one kind is hormonal therapy. Hormonal therapy can be given to women whose breast cancers test positive for estrogen to lower estrogen levels. Letrozole is a third generation of non-steroidal aromatase inhibitor one class of hormonal therapy drugs- that was first introduces by Novartis to the market as Femara for the treatment of local or metastatic breast cancer [3-5].

Non-steroidal aromatase inhibitors (as shown in Figure 1) are triazole or imidazole analogues that bind to the active site of enzyme by coordinating the heme iron atom of active site through a heterocyclic nitrogen lone pair $[5,6]$.

As it shown in Figure 1, 1-benzyl-1H-1,2,4-triazole scaffold is a conservative section of aromatase inhibitors which contains various moieties attached to the aliphatic carbon part of this scaffold. In continuation of our research program to find a novel anticancer agent [7-11], and considering the above mentioned data, in the current study, we 


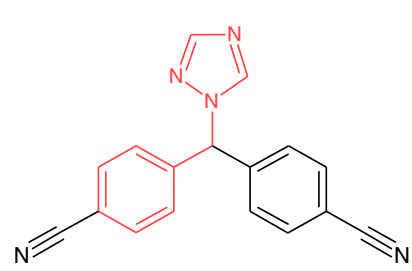

Letrozole

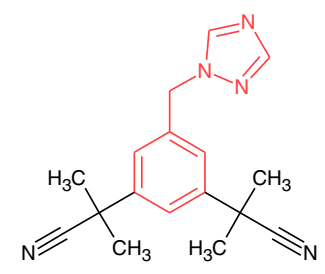

Anastrozole<smiles>Cn1ncc2ccc(C(c3ccc(Cl)cc3)n3cncn3)cc21</smiles>

Vorozole

Figure 1 Structure of non-steroidal aromatase inhibitors.

report the synthesis of a novel series of substituted ethenylbenzene derivatives which linked to1-benzyl-1H-1,2,4triazole $(\mathbf{1 a}-\mathbf{k})$ and evaluated against three human breast cancer cell lines (Scheme 1).

\section{Methods}

\section{Chemistry}

All raw-materials, solvents and reagents were provided from Aldrich Chemicals and Merck AG. A Kofler hot stage apparatus was used for determination of melting points. The IR and ${ }^{1}$ HNMR Spectra were determined on a Shimadzu 470 (potassium bromide disks) and a Bruker 500 spectrophotometer respectively. Tetramethylsilane (TMS) was used as internal standard and chemical shifts are reported in ppm relative to it. The elemental analysis for $\mathrm{C}$, $\mathrm{H}$ and $\mathrm{N}$ were taken by a Perkin-Elmer 843 spectrometer with using $\mathrm{KBr}$ as diluent. Electrospray ionization mass spectra (ESI-MS) were recorded by using Agilent 6410 Triple Quad. LC/MS.

Key intermediate 4-(4-cyanobenzyl)-1,2,4-triazole was prepared according to Doiron J. and his collogues report [12].

\section{General procedure for preparing of 4[2-aryl-1-(1H-1, 2,} 4-triazol-1-yl)ethenyl]benzonitrile (1a-k)

4-(4-Cyanobenzyl)-1,2,4-triazole (1Gr) and 1,4-Dioxane $(10 \mathrm{~mL})$ were added to the reaction vessel and stirred. Sodium hydride $(0.27 \mathrm{Gr} 60 \%)$ was added to the reaction mixture in $0-5^{\circ} \mathrm{C}$ and stirred for 30 minutes. Corresponding aldehyde $(0.5 \mathrm{mmol})$ was added to the mixture and stirred at room temperature for 30 minutes. Ethanol (3 mL) was added to the reaction mixture at $60^{\circ} \mathrm{C}$ and stirred for an hour. Reaction mixture cooled to room temperature and mixture of ice-water (25 Gr) was added. Precipitate was filtered and recrystallized in ethanol to yield corresponding compound (1a-k).

4-[2-Phenyl-1-(1H-1, 2, 4-triazol-1-yl)ethenyl]benzonitrile (1a) Yield: $73 \%, \mathrm{mp} 141-146^{\circ} \mathrm{C}$. IR $\left(\mathrm{KBr}, \mathrm{cm}^{-1}\right) v_{\max }: 2245$ (nitrile), $1630(\mathrm{C}=\mathrm{C}) .{ }^{1} \mathrm{H}$ NMR $\left(500 \mathrm{MHz} \mathrm{CDCl}_{3}\right): \delta$ 8.25(s, $1 \mathrm{H}$, triazole), $8.05(\mathrm{~s}, 1 \mathrm{H}$, triazole), 7.70-7.68 $(\mathrm{d}$, $J=8.55 \mathrm{~Hz}, 2 \mathrm{H}$, benzonitrile), 7.35-7.33 (d, $J=8.55 \mathrm{~Hz}, 2 \mathrm{H}$, benzonitrile), 7.30-7.26 ( $\mathrm{m}$, phenyl and ethenyl), 6.88-6.87 (d, $J=7.3 \mathrm{~Hz}, 1 \mathrm{H}$, phenyl), ESI-Mass $m / z: 272[\mathrm{M}]^{+}$.

\section{4-[2-(2-Chlorophenyl)-1-(1H-1,2,4-triazol-1-yl)ethenyl] benzonitrile (1b)}

Yield: $70 \%, \mathrm{mp} 141-144^{\circ} \mathrm{C}$. IR $\left(\mathrm{KBr}, \mathrm{cm}^{-1}\right) v_{\max }: 2240$ (nitrile), $1622(\mathrm{C}=\mathrm{C}) .{ }^{1} \mathrm{H}$ NMR $\left(500 \mathrm{MHz}, \mathrm{CDCl}_{3}\right): \delta 8.16(\mathrm{~s}$, $1 \mathrm{H}$, triazole), $7.96(\mathrm{~s}, 1 \mathrm{H}$, triazole), $7.72-7.71(\mathrm{~d}, J=8.45 \mathrm{~Hz}$, $2 \mathrm{H}$, benzonitrile), 7.43 (s, $1 \mathrm{H}$, ethenyl), $7.45(\mathrm{~d}, J=7.75 \mathrm{~Hz}$, $1 \mathrm{H}$, phenyl), 7.40-7.39 (d, $J=8.45 \mathrm{~Hz}, 2 \mathrm{H}$, benzonitrile), 7.27-7.23 (t, $J=7.9 \mathrm{~Hz}, 1 \mathrm{H}$, phenyl), 7.08-7.05 (t, $J=J=$ $7.15 \mathrm{~Hz}, 1 \mathrm{H}$, phenyl), 6.61-6.59 (d, $J=7.75 \mathrm{~Hz}, 1 \mathrm{H}$, phenyl), ESI-Mass $m / z: 306[\mathrm{M}]^{+}$.

\section{4-[2-(3-Chlorophenyl)-1-(1H-1,2,4-triazol-1-yl)ethenyl] benzonitrile (1c)}

Yield: $74 \%$, mp $137-140^{\circ} \mathrm{C}$. IR $\left(\mathrm{KBr}, \mathrm{cm}^{-1}\right) v_{\max }: 2242$ (nitrile), $1631(\mathrm{C}=\mathrm{C}) .{ }^{1} \mathrm{H}$ NMR $\left(500 \mathrm{MHz}, \mathrm{CDCl}_{3}\right): \delta 8.25(\mathrm{~s}$, $1 \mathrm{H}$, triazole), $8.04(\mathrm{~s}, 1 \mathrm{H}$, triazole), 7.70-7.69 $(\mathrm{d}, J=8.5 \mathrm{~Hz}$, $2 \mathrm{H}$, benzonitrile), 7.35-7.33 (d, $J=8.5 \mathrm{~Hz}, 2 \mathrm{H}$, benzonitrile), 7.29-7.26 (m, 1H, phenyl), 7.22 (s, 1H, phenyl), 7.20-7.18 (d, J=7.95 Hz, 1H, phenyl), $6.93(\mathrm{~s}, 1 \mathrm{H}$,

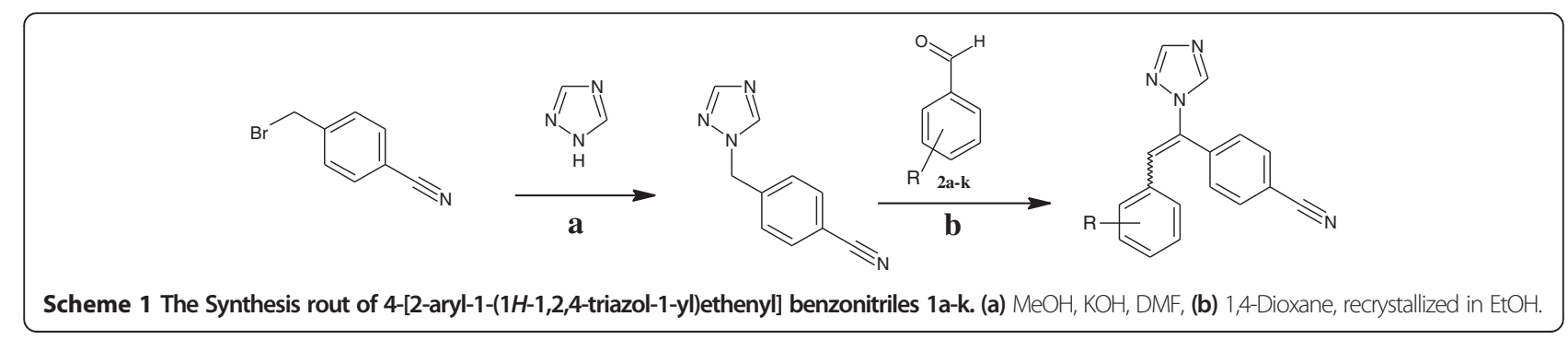


ethenyl), 6.69-6.68 (d, $J=8.2 \mathrm{~Hz}, 1 \mathrm{H}$, phenyl), ESI-Mass $m / z: 306[\mathrm{M}]^{+}$.

\section{4-[2-(4-Chlorophenyl)-1-(1H-1,2,4-triazol-1-yl)ethenyl] benzonitrile (1d)}

Yield: $71 \%$, mp $139-146^{\circ} \mathrm{C}$. IR $\left(\mathrm{KBr}, \mathrm{cm}^{-1}\right) v_{\max }: 2237$ (nitrile), $1630(\mathrm{C}=\mathrm{C}) .{ }^{1} \mathrm{H}$ NMR $\left(500 \mathrm{MHz}, \mathrm{CDCl}_{3}\right) \delta 8.25(\mathrm{~s}$, $1 \mathrm{H}$, triazole), $8.04(\mathrm{~s}, 1 \mathrm{H}$, triazole $), 7.70-7.69(\mathrm{~d}, J=$ $8.86 \mathrm{~Hz}, 2 \mathrm{H}$, benzonitrile), 7.34-7.33 (d, $J=8.6 \mathrm{~Hz}, 2 \mathrm{H}$, benzonitrile), 7.27-7.25 (d, $J=8.5 \mathrm{~Hz}, 2 \mathrm{H}$, phenyl),7.24 (s, $1 \mathrm{H}$, ethenyl), 6.80-6.79(d, $J=8.5 \mathrm{~Hz}, 2 \mathrm{H}$, phenyl), ESI-Mass $m / z: 306[\mathrm{M}]^{+}$.

\section{4-[2-(2,4-Dichlorophenyl)-1-(1H-1,2,4-triazol-1-yl)ethenyl] benzonitrile (1e)}

Yield: $74 \%, \mathrm{mp} 150-153^{\circ} \mathrm{C}$. IR $\left(\mathrm{KBr}, \mathrm{cm}^{-1}\right) v_{\max }: 2248$ (nitrile), $1629(\mathrm{C}=\mathrm{C}) .{ }^{1} \mathrm{H}$ NMR (500 $\left.\mathrm{MHz}, \mathrm{CDCl}_{3}\right): \delta 8.16$ (s, $1 \mathrm{H}$, triazole), $7.96(\mathrm{~s}, 1 \mathrm{H}$, triazole), 7.74-7.72 (d, $J=$ $8.35 \mathrm{~Hz}, 2 \mathrm{H}$, benzonitrile) , 7.42-7.40 (m, 4H, benzonitrile and ethenyl), 7.04-7.01 (m, 1H, phenyl), 6.56-6.55 (m, 1H, phenyl), ESI-Mass $m / z: 340[\mathrm{M}]^{+}$.

\section{4-[2-(3-Fluorophenyl)-1-(1H-1,2,4-triazol-1-yl)ethenyl] benzonitrile (1f)}

Yield: $74 \%, \mathrm{mp} 145-150^{\circ} \mathrm{C}$. IR $\left(\mathrm{KBr}, \mathrm{cm}^{-1}\right) v_{\max }: 2244$ (nitrile), $1634(\mathrm{C}=\mathrm{C}) .{ }^{1} \mathrm{H}$ NMR $\left(500 \mathrm{MHz}, \mathrm{CDCl}_{3}\right): \delta 8.25$ (s, $1 \mathrm{H}$, triazole), $8.05(\mathrm{~s}, 1 \mathrm{H}$, triazole), 7.71-7.69 $(\mathrm{d}, J=$ $8.5 \mathrm{~Hz}, 2 \mathrm{H}$, benzonitrile), 7.35-7.33 (d, $J=8.5 \mathrm{~Hz}, 2 \mathrm{H}$, benzonitrile), 7.30-7.26 (m,1H, phenyl), 7.25 (s, $1 \mathrm{H}$, ethenyl), 7.03-6.99 (m, 1H, phenyl), 6.68-6.66 (d, $J=7.75 \mathrm{~Hz}, 1 \mathrm{H}$, phenyl), 6.58-6.56 (d, $J=7.8 \mathrm{~Hz}, 1 \mathrm{H}$, phenyl), ESI-Mass $\mathrm{m} / z: 290[\mathrm{M}]^{+}$.

\section{4-[2-(3-Methoxyphenyl)-1-(1H-1,2,4-triazol-1-yl)ethenyl] benzonitrile (1 $\mathrm{g}$ )}

Yield: $74 \%, \mathrm{mp} 128-132^{\circ} \mathrm{C}$. IR $\left(\mathrm{KBr}, \mathrm{cm}^{-1}\right) v_{\max }: 2242$ (nitrile), $1631(\mathrm{C}=\mathrm{C}) .{ }^{1} \mathrm{H} \mathrm{NMR}\left(500 \mathrm{MHz}, \mathrm{CDCl}_{3}\right): \delta 8.24$ (s, $1 \mathrm{H}$, triazole), $8.05(\mathrm{~s}, 1 \mathrm{H}$, triazole), 7.69-7.67 $(\mathrm{d}, J=$ $8.1 \mathrm{~Hz}, 2 \mathrm{H}$, benzonitrile), 7.34-7.33 (d, $J=8.1 \mathrm{~Hz}, 2 \mathrm{H}$, benzonitrile), $7.27(\mathrm{~s}, 1 \mathrm{H}$, ethenyl), 7.21-7.18 (t, $J=7.9 \mathrm{~Hz}$, $1 \mathrm{H}$, phenyl), 6.86-6.84 (d, $J=7.6 \mathrm{~Hz}$, phenyl), 6.54-6.53 (d, $J=7.43 \mathrm{~Hz}$, phenyl), 6.31 (s, 1H, phenyl), 3.66 (s,3H,OMe), ESI-Mass $m / z: 302[\mathrm{M}]^{+}$.

\section{4-[2-(4-Methoxyphenyl)-1-(1H-1,2,4-triazol-1-yl)ethenyl] benzonitrile $(1 \mathrm{~h})$}

Yield: $74 \%, \mathrm{mp} 140-143^{\circ} \mathrm{C}$. IR $\left(\mathrm{KBr}, \mathrm{cm}^{-1}\right) v_{\max }: 2244$ (nitrile), $1632(\mathrm{C}=\mathrm{C}) .{ }^{1} \mathrm{H} \mathrm{NMR}\left(500 \mathrm{MHz}, \mathrm{CDCl}_{3}\right) \delta 8.27$ (s, $1 \mathrm{H}$, triazole), $8.08(\mathrm{~s}, 1 \mathrm{H}$, triazole $), 7.67-7.65(\mathrm{~d}, J=$ $8.7 \mathrm{~Hz}, 2 \mathrm{H}$, benzonitrile) , 7.30-7.29 (d , $J=8.7 \mathrm{~Hz}, 2 \mathrm{H}$, benzonitrile), 7.25 (s, $1 \mathrm{H}$, ethenyl), 6.80-6.78 (d, $J=9.2 \mathrm{~Hz}$, $2 \mathrm{H}$, phenyl), 6.77-6.76 (d, $J=9.2 \mathrm{~Hz}, 2 \mathrm{H}$, phenyl), 3.80 (s,3H, OMe), ESI-Mass $m / z: 302[\mathrm{M}]^{+}$.
4-[2-(2,4-Dimethoxyphenyl)-1-(1H-1,2,4-triazol-1-yl)ethenyl] benzonitrile (1i)

Yield: $74 \%, \mathrm{mp} 158-161^{\circ} \mathrm{C}$. IR $\left(\mathrm{KBr}, \mathrm{cm}^{-1}\right) v_{\max }: 2239$ (nitrile), $1632(\mathrm{C}=\mathrm{C}) .{ }^{1} \mathrm{H}$ NMR $\left(500 \mathrm{MHz}, \mathrm{CDCl}_{3}\right): \delta 8.22$ (s, $1 \mathrm{H}$, triazole), $8.06(\mathrm{~s}, 1 \mathrm{H}$, triazole $), 7.66-7.65(\mathrm{~d}, J=$ $8.3 \mathrm{~Hz}, 2 \mathrm{H}$, benzonitrile), 7.50 (s, 1H, ethenyl ), 7.31-7.30 (d, $J=8.3 \mathrm{~Hz}, 2 \mathrm{H}$, benzonitrile), 6.44-6.27 (m, 3H, phenyl), 3.84 (s,3H, OMe), 3.79 (s,3H, OMe), ESI-Mass m/z: $332[\mathrm{M}]^{+}$.

\section{4-[2-(2,3,4-Trimethoxy)-1-(1H-1,2,4-triazol-1-yl)ethenyl] benzonitrile (1j)}

Yield: $75 \%, \mathrm{mp} 188-191^{\circ} \mathrm{C}$. IR $\left(\mathrm{KBr}, \mathrm{cm}^{-1}\right) v_{\max }: 2246$ (nitrile), $1634(\mathrm{C}=\mathrm{C}) .{ }^{1} \mathrm{H}$ NMR $\left(500 \mathrm{MHz}, \mathrm{CDCl}_{3}\right): \delta 8.20$ (s, $1 \mathrm{H}$, triazole), $8.09(\mathrm{~s}, 1 \mathrm{H}$, triazole $), 7.67-7.65(\mathrm{~d}, J=$ $8.3 \mathrm{~Hz}, 2 \mathrm{H}$, benzonitrile), 7.51 (s, $1 \mathrm{H}$, ethenyl ), 7.33-7.30 (d, $J=8.3 \mathrm{~Hz}, 2 \mathrm{H}$, benzonitrile), 6.46-6.25 ( $\mathrm{m}, 2 \mathrm{H}$, phenyl), 3.86 (s,3H, OMe), 3.81 (s,3H, OMe), 3.76 (s,3H, OMe), ESIMass $m / z: 3362[\mathrm{M}]^{+}$.

\section{4-[2-(4-Dimethylamino)-1-(1H-1,2,4-triazol-1-yl)ethenyl]} benzonitrile (1 $\mathrm{k}$ )

Yield: $72 \%, \mathrm{mp} 158-161^{\circ} \mathrm{C}$. IR $\left(\mathrm{KBr}, \mathrm{cm}^{-1}\right) v_{\max }: 2241$ (nitrile), $1633(\mathrm{C}=\mathrm{C}) .{ }^{1} \mathrm{H}$ NMR $\left(500 \mathrm{MHz}, \mathrm{CDCl}_{3}\right) \delta 8.26$ (s, $1 \mathrm{H}$, triazole), $8.05(\mathrm{~s}, 1 \mathrm{H}$, triazole $), 7.66-7.65(\mathrm{~d}, J=$ $8.5 \mathrm{~Hz}, 2 \mathrm{H}$, benzonitrile), 7.32-7.27 (d, $J=8.5 \mathrm{~Hz}, 2 \mathrm{H}$, benzonitrile), 7.25 (s, $1 \mathrm{H}$, ethenyl), 6.79-6.75 (d, $J=9.1 \mathrm{~Hz}, 2 \mathrm{H}$, phenyl), 6.74-6.72 (d, J=9.1 Hz, 2H, phenyl), 3.79-3.75 (m,6H, Me), ESI-Mass $m / z: 315[\mathrm{M}]^{+}$.

\section{Physicochemical prediction}

Marvin was used for chemical drawing, displaying and characterizing chemical structures, calculator plugins were used for structure property prediction and calculation, (version: Marvin 6.0.3, 2013, ChemAxon scientific package, http://www.chemaxon.com).

\section{Molecular modeling study}

Docking studies for selected compounds were performed using Autodock Vina (ver. 1.1.1) [13]. The crystal structure of human placental aromatase cytochrome P450 in complex with androstenedione (code ID: 3EQM, resolution $[\AA]$ : 2.90) was retrieved from protein data bank [14-17]. Crystal structure was cleaned from Co-crystallized ligand and water molecules and the protein was converted to pdbqt format using Autodock Tools (1.5.4) [18]. 2Dstructures of ligands converted to $3 \mathrm{D}$ in pdbqt format by Openbabel (ver. 2.3.1) [18]. The docking parameters were set on vina docking parameter as follow: center_x $=85.027$; center_y $=$ 54.737; center_ $z=46.428$; size_ $x=50$; size_y $=50$; size_ $z=50$;. The other parameters were left as default for the program. Finally, the conformation for the best free energy of binding was selected for analyzing the interactions between the macromolecule and selected inhibitors. 3D 
<smiles></smiles>

\begin{tabular}{|c|c|c|c|c|c|c|c|}
\hline No. & Comp. Code & $\mathrm{Ar}$ & MW & Formula & $\begin{array}{l}\text { Vander Waals } \\
\text { Surface }\end{array}$ & Polar Surface & $\log P$ \\
\hline 1. & $1 a$ & & 272 & $\mathrm{C}_{17} \mathrm{H}_{12} \mathrm{~N}_{4}$ & 363.21 & 54.50 & 3.12 \\
\hline 2. & $1 b$ & & 306.75 & $\mathrm{C}_{17} \mathrm{H}_{11} \mathrm{ClN}_{4}$ & 376.65 & 54.50 & 3.72 \\
\hline 3. & 1c & & 306.75 & $\mathrm{C}_{17} \mathrm{H}_{11} \mathrm{ClN}_{4}$ & 378.12 & 54.50 & 3.72 \\
\hline 4. & $1 d$ & & 306.75 & $\mathrm{C}_{17} \mathrm{H}_{11} \mathrm{ClN}_{4}$ & 378.12 & 54.50 & 3.72 \\
\hline 5. & $1 e$ & & 341.19 & $\mathrm{C}_{17} \mathrm{H}_{10} \mathrm{Cl}_{2} \mathrm{~N}_{4}$ & 393.15 & 54.50 & 4.33 \\
\hline 6. & $1 \mathrm{f}$ & & 290.29 & $\mathrm{C}_{17} \mathrm{H}_{11} \mathrm{FN}_{4}$ & 369.04 & 54.50 & 3.22 \\
\hline 7. & $1 \mathrm{~g}$ & & 302.33 & $\mathrm{C}_{18} \mathrm{H}_{14} \mathrm{ON}_{4}$ & 410.22 & 63.73 & 2.96 \\
\hline 8. & $1 \mathrm{~h}$ & & 302.33 & $\mathrm{C}_{18} \mathrm{H}_{14} \mathrm{ON}_{4}$ & 409.36 & 63.73 & 2.96 \\
\hline 9. & $1 i$ & & 332.36 & $\mathrm{C}_{19} \mathrm{H}_{16} \mathrm{O}_{2} \mathrm{~N}_{4}$ & 457.69 & 72.96 & 2.80 \\
\hline 10. & $1 \mathrm{j}$ & & 362.38 & $\mathrm{C}_{20} \mathrm{H}_{18} \mathrm{O}_{3} \mathrm{~N}_{4}$ & 504.76 & 82.19 & 2.65 \\
\hline 11. & $1 \mathrm{k}$ & & 315.37 & $\mathrm{C}_{19} \mathrm{H}_{17} \mathrm{~N}_{5}$ & 448.10 & 57.74 & 3.23 \\
\hline
\end{tabular}

models of ligand-receptor interactions are generated by using the Autodock Tools (1.5.4) [19].

\section{Biological assay}

\section{Cell lines and cell culture}

Three human breast cancer cell lines including MDA-MB231, MCF-7 and T-47D were obtained from National Cell Bank of Iran (NCBI, Iran). The cells were grown in RPMI-
1640 medium supplemented with $10 \%$ heat-inactivated fetal calf serum (GibcoeBRL, UK), $100 \mathrm{mg} / \mathrm{ml}$ streptomycin and $100 \mathrm{U} / \mathrm{ml}$ penicillin at $37^{\circ} \mathrm{C} / 95 \% \mathrm{rh} / 5 \% \mathrm{CO}_{2}$.

\section{In vitro cytotoxicity assay}

The in-vitro cytotoxic activity of all synthesized compounds 1a-k was achieved against three human breast cancer cell lines using MTT colorimetric assay according 
Table 2 In vitro cytotoxic activity $\left(\mathrm{IC}_{50}, \mu \mathrm{g} / \mathrm{ml}\right)$ of compounds 1a-k against breast cancer cell lines ${ }^{a}$

\begin{tabular}{lcccr}
\hline No. & $\begin{array}{l}\text { Comp. } \\
\text { Code }\end{array}$ & \multicolumn{3}{l}{ Cell lines } \\
\cline { 3 - 5 } & MCF-7 & MDA-MB-231 & \multicolumn{1}{c}{ T-47D } \\
\hline 1. & $1 \mathrm{a}$ & $57.1 \pm 2.1$ & $87.5 \pm 2.5$ & $64.3 \pm 1.9$ \\
2. & $1 \mathrm{~b}$ & $63.2 \pm 2.6$ & $97.3 \pm 3.1$ & $77.1 \pm 2.8$ \\
3. & $1 \mathrm{C}$ & $27.1 \pm 1.2$ & $14.5 \pm 2.1$ & $76.25 \pm 7.0$ \\
4. & $1 \mathrm{~d}$ & $52.3 \pm 2.2$ & $43.3 \pm 3.4$ & $83.3 \pm 5.2$ \\
5. & $1 \mathrm{e}$ & $78.3 \pm 5.7$ & $83.3 \pm 7.2$ & $92.3 \pm 6.2$ \\
6. & $1 \mathrm{f}$ & $72.3 \pm 5.5$ & $85.3 \pm 7.4$ & $87.3 \pm 7.5$ \\
7. & $1 \mathrm{~g}$ & $40.3 \pm 2.8$ & $77.4 \pm 6.5$ & $69.4 \pm 5.7$ \\
8. & $1 \mathrm{~h}$ & $74.6 \pm 6.5$ & $82.3 \pm 7.4$ & $14.3 \pm 1.1$ \\
9. & $1 \mathrm{i}$ & $75.3 \pm 4.4$ & $89.4 \pm 6.1$ & $79.1 \pm 7.7$ \\
10. & $1 \mathrm{j}$ & $69.3 \pm 5.3$ & $45.05 \pm 6.2$ & $63.3 \pm 6.6$ \\
11. & $1 \mathrm{k}$ & $55.3 \pm 5.1$ & $19.7 \pm 1.8$ & $16.8 \pm 2.1$ \\
12. & Etoposide & $7.9 \pm 0.5$ & $11.1 \pm 1.1$ & $8 \pm 0.8$ \\
\hline
\end{tabular}

${ }^{a}$ The $\mathrm{IC}_{50}$ values represent an average of three independent experiments (mean \pm SD). to the method of Mosman [20]. Cells were seeded in 96well plates (Nunc, Denmark) and incubated overnight in a humidified air atmosphere at $37^{\circ} \mathrm{C}$ with $5 \% \mathrm{CO}_{2}$ to allow cell attachment. The cells were then incubated for another $48 \mathrm{~h}$ with various concentrations of compounds 1a-k. The final concentration of DMSO in the highest concentration of the applied compounds was $1 \%$. In each plate, there were three control wells (cells without test compounds) and three blank wells (the medium with 1\% DMSO) for cell viability. Etoposide were used as positive controls for cytotoxicity. After $48 \mathrm{~h}$, the culture medium was removed and $200 \mu \mathrm{l}$ phenol red-free medium containing MTT (final concentration $0.5 \mathrm{mg} / \mathrm{mL}$ ) was added to wells, followed by $4 \mathrm{~h}$ incubation.

After incubation, the culture medium was then replaced with $100 \mu \mathrm{l}$ of DMSO and the absorbance of each well was measured by using a microplate reader at $492 \mathrm{~nm}$. For each compound, the concentration causing $50 \%$ cell growth inhibition $\left(\mathrm{IC}_{50}\right)$ compared with the control containing 1\% DMSO was calculated from concentration response curves by regression analysis.

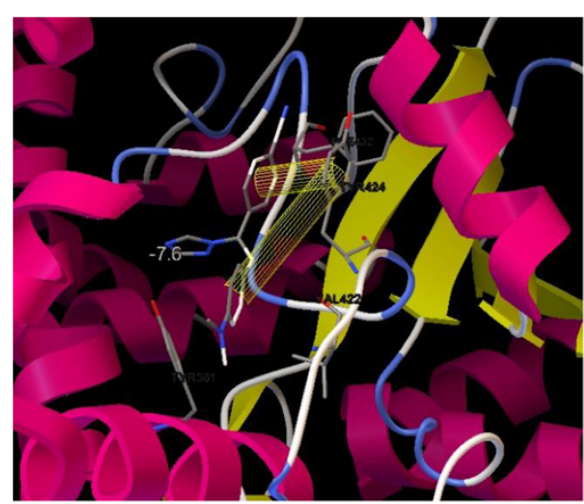

$\mathbf{a}$

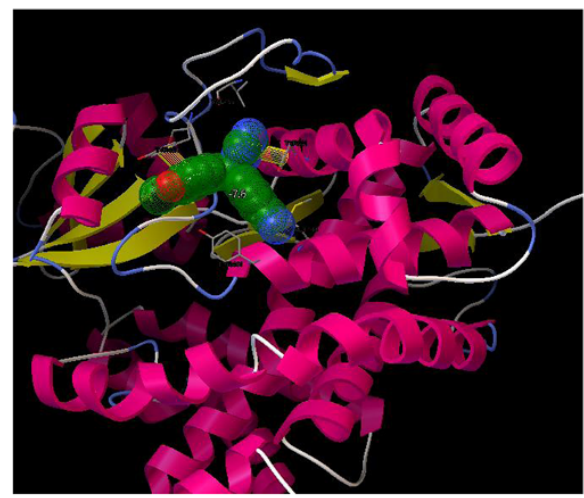

c

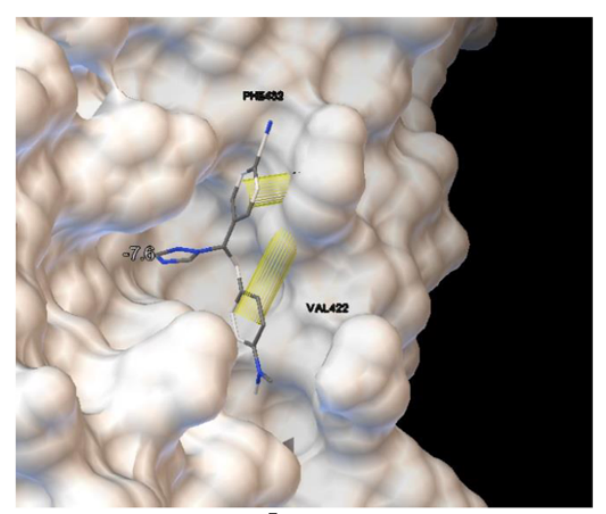

b

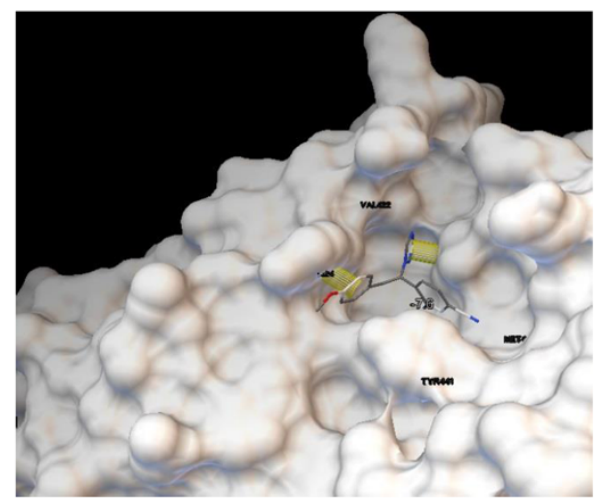

d

Figure 2 Presentation of compounds (1c) and (1 k) with aromatase enzyme, $\pi-\pi$ interactions showed in yellow cylindrical shape. $(\mathbf{a}, \mathbf{b})$ visualization of compound (1c) in enzyme with ribbon and molecular surface views; $(\mathbf{c}, \mathbf{d})$ binding mode of (1 $\mathbf{k})$ in enzyme with ribbon and molecular surface views. 


\section{Results and discussions Chemistry}

4-Bromotolunitrile was converted to 4-(4-cyanobenzyl)-1,2,4-triazole and subsequently to corresponding product, 4-[2-aryl-1-(1H-1,2,4-triazol-1-yl)ethenyl]benzonitrile (1a-k) according to the procedure presented in Scheme 1. Chemical structures, molecular formula and molecular weight of compounds (1a-k) are illustrated in Table 1. Reaction yields are presented in chemistry section of methods in this report.

\section{Physicochemical prediction}

In order to investigate the physicochemical properties of products, Vander Waals surface, polar surface and partition-coefficient ( $\log \mathrm{P})$ of compounds $(\mathbf{1} \mathbf{a}-\mathbf{k})$ were predicted by Marvin program and are reported in Table 1. As it shown primary physicochemical criteria were passed by all designed compounds (1a-k).

\section{Cytotoxic activity}

The in vitro cytotoxic activity of 4[2-aryl-1-(1H-1,2,4-triazol1-yl)ethenyl]benzonitrile (1a-k), were tested against three human breast cancer lines including MDA-MB-231, T47D and MCF-7. The various concentrations of the synthetic compounds (final concentration 5, 10, 20, 40, 80 and $100 \mu \mathrm{g} / \mathrm{ml}$ ) were applied to calculate $\mathrm{IC}_{50}$. The $50 \%$ growth inhibitory concentration $\left(\mathrm{IC}_{50}\right)$ for products were calculated and depicted in Table 2.

According to MTT assay results in Table 2, 4-[2-(3chlorophenyl)-1-(1H-1,2,4-triazol-1-yl)ethenyl]benzonitrile (1c) showed the highest activity against MCF-7 and MDA-MB-231 cell lines with $\mathrm{IC}_{50}$ values of $27.1 \pm 1.2$ and $14.5 \pm 2.1 \mu \mathrm{g} / \mathrm{ml}$, respectively and 4-[2-(4-methoxyphenyl)-1-(1H-1,2,4-triazol-1-yl)ethenyl]benzonitrile (1 h) exhibited highest activity against $\mathrm{T} 47 \mathrm{D}$ cell line with $\mathrm{IC}_{50}$ value of $14.3 \pm 1.1 \mu \mathrm{g} / \mathrm{ml}$. As can be seen in Table 2, compound 4-[2-(4-dimethylamino)-1-(1H-1,2,4-triazol-1yl)ethenyl]benzonitrile $(\mathbf{1} \mathbf{k})$, showed comparative activity against T47D and MDA-MB-231 cell lines with compound $\mathbf{1 ~ h}$ and Etoposide withIC $C_{50}$ values of $16.8 \pm 2.1$ and $19.7 \pm 1.8 \mu \mathrm{g} / \mathrm{ml}$, respectively. As it shown in MTT assay results all other synthesized compound did not show good activity against tested cell lines.

\section{Docking study}

In order to understand the binding mode of active compounds in the active site pocket of aromatase, docking study was performed using Autodock Vina. To attain this aim, the potent compounds, $\mathbf{1} \mathbf{c}$ and $\mathbf{1} \mathbf{k}$ were docked into target enzyme. Docking strongly suggested that the $\pi-\pi$ interaction between adjacent phenyl rings and hydrophobic moieties in enzyme residues - Tyrosine 424 and Tyrosine 361- are effective in activity of biologically active synthesized compounds. According to Figure 2, selected compounds fit in the pocket of aromatase enzyme completely, however missing the potentially hydrogen bond between ligands and macromolecule is responsible for moderate activities of compounds (1c) and $(\mathbf{1} \mathbf{k})$.

\section{Conclusion}

In the process of anti-cancer drug discovery, to find new potential anti-breast cancer agents, we designed and synthesized a novel series of letrozole analogs. Cytotoxicity evaluation revealed that compounds (1c) and (1 k) were the most potent compounds with comparative activity with Etoposide. Physicochemical properties of products predicted and the binding mode of $(\mathbf{1 c})$ and $(\mathbf{1} \mathbf{k})$ were predicted by docking simulation; the results revealed that $\pi-\pi$ interactions are responsible for the enzyme inhibitions of compounds (1) and $(\mathbf{1} \mathbf{k})$.

\section{Competing interests}

The authors declare that they have no competing interests.

\section{Authors' contributions}

MV: design and synthesis of the title compound, manuscript preparations. LF: computational design for prediction of physicochemical properties. AR: collaboration in the synthesis of the target compounds. MP: collaboration in cytotoxic assay. MS: collaboration in cytotoxic assays and $\mathrm{IC}_{50}$ calculations. SKA: supervision of the pharmacological part. AD: reporting the spectra and writing experimental section. AA: collaboration in the synthesis of intermediates. KD: collaboration in cytotoxic assays. AF: design of target compounds and the synthetic rout. All authors read and approved the final manuscript.

\section{Acknowledgments}

This work was supported by a grant from Iran National Science Foundation (INSF).

\section{Author details}

'Department of Medicinal Chemistry, Faculty of Pharmacy, Tehran University of Medical Sciences, Tehran, Iran. ${ }^{2}$ Drug Design and Development Research Center, Tehran University of Medical Sciences, Tehran, Iran. ${ }^{3}$ Institute of Biochemistry and Biophysics, University of Tehran, PO Box 13145-1384, Tehran, Iran. ${ }^{4}$ Department of Biotechnology, Iranian Research Organization for Science and Technology, Tehran, Iran. ${ }^{5}$ Neuroscience Research Center, Institute of Neuropharmacology, Kerman University of Medicinal Sciences, Kerman, Iran. ${ }^{6}$ Pharmaceutical Sciences Research Center, Tehran University of Medical Sciences, Tehran, Iran.

\section{Received: 22 September 2014 Accepted: 8 December 2014}

Received: 22 September 2014 Accepted: 8

\section{References}

1. Dutta U, Pant K: Aromatase inhibitors: past, present and future in breast cancer therapy. Med Oncol 2008, 25:113-124.

2. Vicini F, Beitsch $P$, Quiet $C$, Gittleman M, Zannis V, Fine $R$, Whitworth $P$, Kuerer H, Haffty B, Keisch M, Lyden M: Five-year analysis of treatment efficacy and cosmesis by the American society of breast surgeons mammo site breast brachytherapy registry trial in patients treated with accelerated partial breast irradiation. Int J Radiant Oncol Biol Phys 2011, 79:808-817.

3. Smith GL, Xu Y, Buchholz TA, Giordano SH, Jiang J, Shih YC, Smith BD: Association between treatment with brachytherapy vs. whole-breast irradiation and subsequent mastectomy, complications, and survival among older women with invasive breast cancer. JAMA 2012, 307:1827-1837.

4. Cox JA, Swanson TA: Current modalities of accelerated partial breast irradiation. Nat Rev Clin Oncol 2013, 10:344-356.

5. Caporuscio F, Rastelli G, Imbriano C, Delrio A: Structure-based design of potent aromatase inhibitors by high-throughput docking. J Med Chem 2011, 54:4006-4017. 
6. Dowsett M, Cuzick J, Ingle J, Coates A, Forbes J, Bliss J, Buyse M, Baum M, Buzdar A, Colleoni M, Coombes C, Snowdon C, Gnant M, Jakesz R, Kaufmann M, Boccardo F, Godwin J, Davies C, Peto R: Meta-analysis of breast cancer outcomes in adjuvant trials of aromatase inhibitors versus tamoxifen. J Clin Oncol 2010, 28:509-518.

7. Zonouzi A, Mirzazadeh R, Safavi M, Kabudanian Ardestani S, Emami S, Foroumadi A: 2-Amino-4-(nitroalkyl)-4H-chromene-3-carbonitriles as New Cytotoxic Agents. Iran J Pharm Res 2013, 12:679-685.

8. Vosooghi M, Yahyavi H, Divsalar K, Shamsa H, Kheirollahi A, Safavi M, Ardestani SK, Sadeghi-Neshat S, Mohammadhosseini N, Edraki N, Khoshneviszadeh M, Shafiee A, Foroumadi A: Synthesis and In vitro cytotoxic activity evaluation of (E)-16-(substituted benzylidene) derivatives of dehydroepiandrosterone. Daru J Pharm Sci 2013, 21:34.

9. Ketabforoosh S H M E, Kheirollahi A, Safavi M, Esmati N, Ardestani S K, Emami S, Firoozpour L, Shafiee A, A Foroumadi A: Synthesis and anti-cancer activity evaluation of new dimethoxylated chalcone and flavanone analogs. Arch. Pharm. (Weinheim) 2014, in press: doi:10.1002/ardp.201400215.

10. Noushini S, Alipour E, Emami S, Safavi M, Ardestani SK, Gohari AR, Shafiee A, Foroumadi A: Synthesis and cytotoxic properties of novel (E)-3benzylidene-7-methoxychroman-4-one derivatives. Daru J Pharm Sci 2013, 2:31.

11. Alipour E, Mousavi Z, Safaei Z, Pordeli M, Safavi M, Firoozpour L, Mohammadhosseini N, Saeedi M, Ardestani SK, Shafiee A, Foroumadi A: Synthesis and cytotoxic evaluation of some new[1,3]dioxolo[4,5-g] chromen-8-one derivatives. Daru J Pharm Sci 2014, 22:41.

12. Doiron J, Soultan AH, Richard R, Touré MM, Picot N, Richard R, Cuperlović-Culf M, Robichaud GA, Touaibia M: Synthesis and structure-activity relationship of 1- and 2-substituted-1,2,3-triazole letrozole-based analogues as aromatase inhibitors. Eur J Med Chem 2011, 46:4010-4024.

13. Trott O, Olson AG: Software news and update AutoDockVina: improving the speed and accuracy of docking with a new scoring function, efficient optimization, and multithreading. J Comput Chem 2010, 31:455-461

14. Ghosh D, Griswold J, Erman M, Pangborn W: Structural basis for androgen specificity and oestrogen synthesis in human aromatase. Nature 2009, 457:219-223.

15. Suvannang N, Nantasenamat C, Isarankura-Na-Ayudhya C, Prachayasittikul V: Molecular docking of aromatase inhibitors. Molecules 2011, 16:3597-3617.

16. Thakur A, Timiri AK: Designing of potential new aromatase inhibitor for estrogen dependent disease: a computational approach. World J Pharm Sci 2014, 2:13-24.

17. Mirzaie S, Chupani L, Barzegari Asadabadi E, Shahverdi AR, Jamalan M: Novel inhibitor discovery against aromatase through virtual screening and molecular dynamic simulation: a computational approach in drug design. EXCLI J 2013, 12:168-183.

18. Sanner MF: Python: a programming language for software integration and development. J Mol Graph Mod 1999, 17:57-61.

19. O'Boyle NM, Banck M, James CA, Morley C, Vandermeersch T, Hutchison GR: Open babel: an open chemical toolbox. J Cheminform 2011, 3:33.

20. Mosmann T: Rapid colorimetric assay for cellular growth and survival: application to proliferation and cytotoxicity assays. J Immunol Methods 1983, 65:55-63.

doi:10.1186/s40199-014-0083-4

Cite this article as: Vosooghi et al:: Design, synthesis, docking study and cytotoxic activity evaluation of some novel letrozole analogs. DARU Journal of Pharmaceutical Sciences 2014 22:83.

\section{Submit your next manuscript to BioMed Central and take full advantage of:}

- Convenient online submission

- Thorough peer review

- No space constraints or color figure charges

- Immediate publication on acceptance

- Inclusion in PubMed, CAS, Scopus and Google Scholar

- Research which is freely available for redistribution

Submit your manuscript at www.biomedcentral.com/submit 